\title{
Prevention of apoptosis in J2E erythroid cells by erythropoietin: involvement of JAK2 but not MAP kinases
}

\author{
David Chappell ${ }^{1,2}$, Peta A. Tilbrook ${ }^{1}$, Thomas Bittorf ${ }^{3}$, Shane \\ M. Colley ${ }^{1}$, Geoffrey T. Meyer ${ }^{4}$ and S. Peter Klinken ${ }^{1,5}$ \\ 1 Department of Biochemistry, Royal Perth Hospital, GPO Box X2213, Perth WA \\ 6001, Australia \\ 2 The University of Western Australia, \\ ${ }^{3}$ Institute of Medical Biochemistry University of Rostock, Germany \\ ${ }^{4}$ Department of Anatomy and Human Biology, The University of Western \\ Australia, Nedlands WA 6009, Australia \\ ${ }^{5}$ corresponding author: S. Peter Klinken tel: (9) 224 2426, fax: (9) 2242491
}

Received 23.5.96; revised 7.8.96; accepted 8.8.96

Edited by R.A. Knight

\begin{abstract}
The J2E erythroid cell line, transformed by retroviral v-raf/vmyc oncogenes, proliferates and differentiates in response to erythropoietin. Here we show that J2E cells undergo apoptosis rapidly after serum withdrawal and that only erythropoietin of seven growth factors tested, could protect the cells from death. The role of JAK2 and MAP kinases in transmitting viability signals initiated by erythropoietin was examined in these cells. Despite constituitive raf kinase activity, phosphorylation of MAP kinases fell after serum withdrawal. However, an antisense oligonucleotide strategy revealed that JAK2, but not the MAP kinases, was involved in transmitting signals to maintain the viability of J2E cells. Several cell cycle proteins and transcription factors were also studied; although c-jun rose sharply during apoptosis, erythropoietin could not suppress this increase. It was concluded that erythropoietin-induced protection from apoptosis involved JAK2, but not MAP kinases or c-jun.
\end{abstract}

Keywords: erythropoietin, apoptosis, JAK2, MAP kinases, cjun

Abbreviations: epo, erythropoietin; MEL, murine erythroleukemia; FCS, fetal calf serum; DMEM, Dulbecco's modified Eagle's medium; MAP kinases, mitogen activated protein kinases; JAK2, Janus kinase 2; SCF, Stem cell factor; IL-3, interleukin 3; GM-CSF, granulocyte macrophage colony stimulating factor; IGF-1, insulin-like growth factor 1; PCNA, proliferating cell nuclear antigen; G-CSF, granulocyte colony stimulating factor.

\section{Introduction}

Erythropoiesis is regulated by the glycoprotein hormone erythropoietin (epo), which acts by binding to specific receptors on erythroid precursor cells, thereby promoting growth and differentiation into mature red blood cells (Krantz, 1991; Jelkmann, 1992; Koury and Bondurant, 1992). The action of epo has been studied in primary cell cultures and transformed cell lines, and the signal transduction mechanism of the hormone is gradually being elucidated (Koury and Bondurant, 1992; Wojchowski and He, 1993; Ihle, 1995). Various laboratories have reported that the processes of proliferation and differentiation in erythroid cells can be separated (Noguchi et al, 1988; Sytkowski et al, 1980, Liboi et al, 1993; Busfield and Klinken, 1992), which suggests that they are mediated by different pathways. It has also been demonstrated that epo is involved in preventing the death of erythroid precursors (Koury and Bondurant, 1988, 1990; Spivak et al, 1991). Studies on Friend virus-infected erythroid cells and the epo-dependent HCD-57 line have shown that epo retards DNA breakdown and maintains cell viability (Koury and Bondurant, 1988, 1990; Spivak et al, 1991). Our recent studies have indicated that distinct epo-induced signalling pathways may exist in cells which lead to cell division, maturation and maintenance of viability (Tilbrook et al, 1996a). In addition, IL-2, IL-3 and GM-CSF transmit signals that promote cell survival, independent of initiating cell division (Okuda et al, 1994; Inhorn et al, 1995; Kinoshita et al, 1995; Boise et al, 1995).

Apoptosis is the term used to describe physiological cell death which may be initiated either by external signals, or by the lack of viability factors, and appears to be programmed by the cell (Kerr et al, 1972; Wyllie et al, 1980; Raff, 1992). One of the characteristic features of cells undergoing apoptosis is nuclear condensation and fragmentation. These membrane-bound apoptotic bodies are clearly visible by light and electron microscopy. Additionally, DNA in apoptotic cells is degraded by endogenous endonucleases and typical nucleosomal banding patterns can be observed by gel electrophoresis (Koury and Bondurant, 1990; Williams et al, 1990; Spivak et al, 1991).

In this report, we describe the susceptibility of the erythroid J2E cell line to apoptosis. This clonal population of cells was immortalized at the proerythroblast stage of development by infection with the $\mathrm{J} 2$ virus containing the $\mathrm{v}$ raf and v-myc oncogenes (Klinken et al, 1988). The cells do not require epo for growth in culture, but respond to the hormone by proliferating and terminally differentiating (Klinken et al, 1988; Busfield and Klinken, 1992; Busfield et al, 1993a,b,c, 1995a,b; Callus et al, 1995; Tilbrook et al, $1996 a, b)$. We show here that the J2E cells become committed to apoptosis $4-6 \mathrm{~h}$ after withdrawal of fetal calf serum (FCS), and only epo, of seven growth factors tested, was able to inhibit cell death. Experiments with intracellular signalling molecules revealed that Janus kinase 2 (JAK2) plays an important role in epo signalling for cell viability, whereas mitogen activated protein (MAP) kinases do not appear to be involved in this process. 


\section{Results}

\section{J2E cells undergo apoptosis after serum withdrawal}

As most cell lines require growth and viability factors present in FCS for survival, we investigated the effect of removing serum from J2E cultures. Figure 1a shows that the viability of J2E cells was dependent on the concentration of FCS - below $5 \%$ FCS the viability of J2E cells fell dramatically. This decrease was time dependent, and could be reversed by reintroduction of FCS up to $4 \mathrm{~h}$ after serum deprivation (Figure 1b). Thereafter, fewer cells could be rescued and commitment to cell death appeared irrevocable. Significantly, DNA synthesis ceased within $3 \mathrm{~h}$ of FCS removal (data not shown).

To determine if the cells were undergoing programmed cell death, their morphology was examined after serum withdrawal. Cells were collected and stained with May-
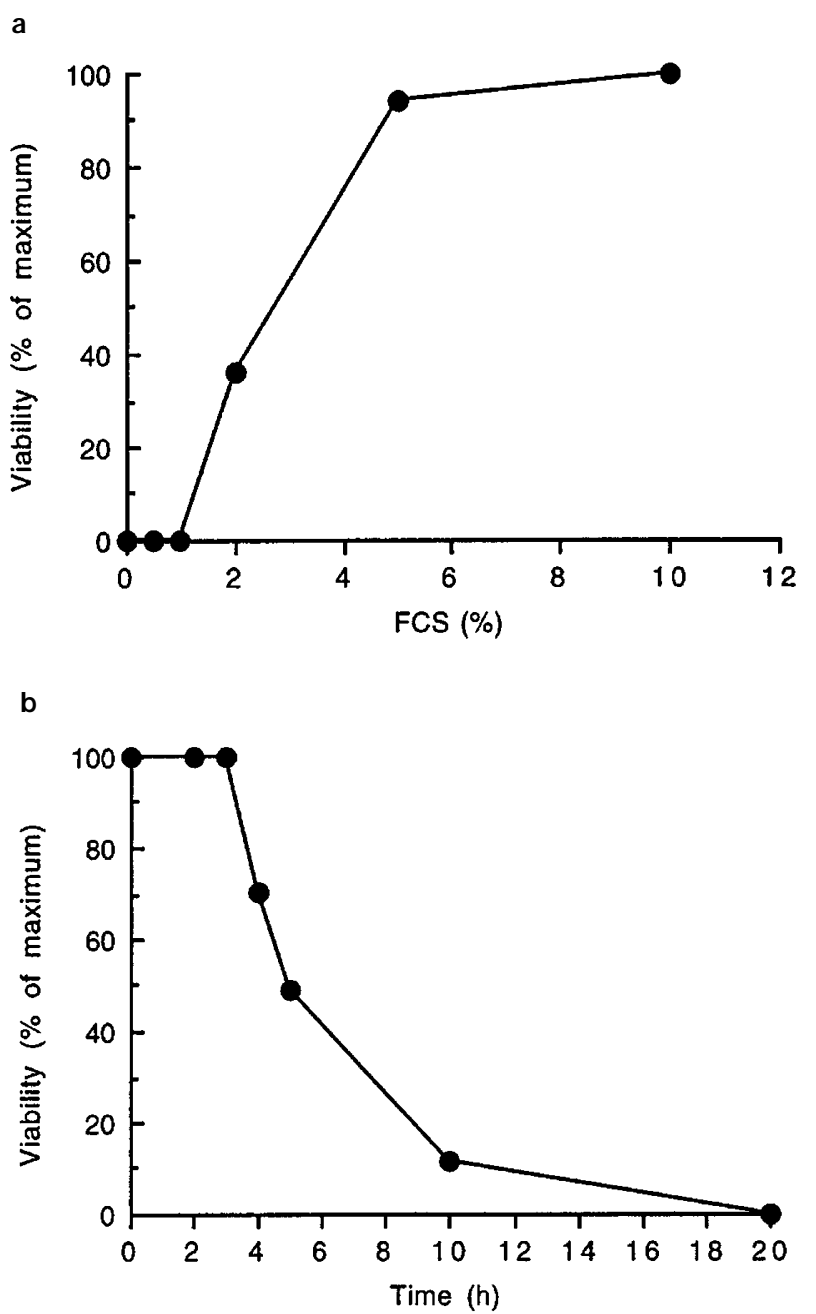

Figure 1 Serum withdrawal results in rapid death of J2E cells. (a) J2E cells were washed thoroughly and replated with different concentrations of FCS. The following day viability was assessed. (b) Cells were washed and cultured in media without FCS. At various time points FCS (10\%) was re-introduced into the cultures and viability assessed after $24 \mathrm{~h}$. These experiments are representative of three separate experiments.

Grunwald-Geimsa and two DNA-binding flurochromes (Figure 2). Unlike normal J2E cells in culture, the serumstarved cells appeared smaller and contained fragmented nuclei (Figure 2a). Fluorescence microscopy using acridine orange and $\mathrm{H} 33258$ revealed that the highly condensed fragments did indeed contain DNA (Figure $2 \mathrm{~b}$ and $\mathrm{c}$ ). These data were confirmed by the strong correlation between the number of cells with degraded DNA, as identified by Apotag staining, and cells unable to exclude eosin $(r=0.96)$.

To investigate this phenomenon in greater detail, electron microscopy was employed to view the cells at higher magnification. Figure 3 shows some normal J2E cells with large nuclei and diffuse chromatin structure; organelles such as mitochondria, endoplasmic reticulum and ribosomes are clearly visible. In contrast, other cells in these cultures displayed nuclear condensation and fragmentation, decreased cell volume and condensed membrane-bound organelles. These features are characteristic of cells undergoing apoptosis (Kerr et al, 1972; Wyllie et al, 1980; Raff, 1992).

Another feature commonly associated with programmed cell death is the nucleosomal banding pattern of degrading DNA. When DNA was extracted from J2E cells and separated by gel electrophoresis, nucleosomal banding associated with DNA degradation increased markedly with time (Figure 4). The breakdown of DNA could also be demonstrated by propidium iodide staining and FACS analysis as cells with less than diploid DNA content
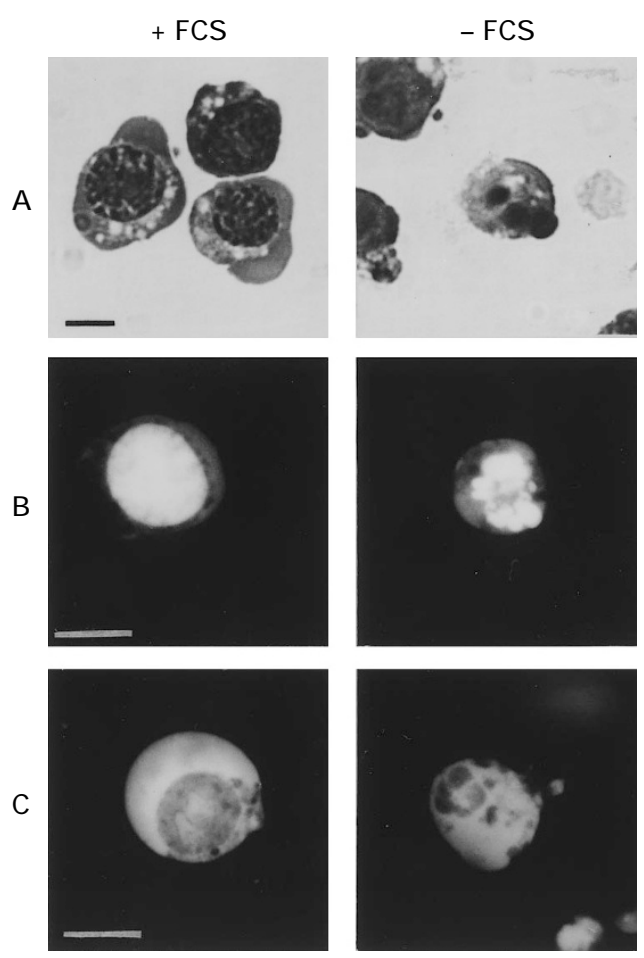

Figure 2 Morphological changes after serum withdrawal. J2E cells were grown with, or without, FCS for $24 \mathrm{~h}$, then cytocentrifuged onto glass slides and stained with either May Grunwald Giemsa (A) bisbenzimide H33258 (B) or acridine orange $(\mathrm{C})$. 
accumulated (data not shown). These data are consistent with the notion that the cells were undergoing apoptosis, and confirmed that removal of FCS initiated programmed cell death in J2E cultures.

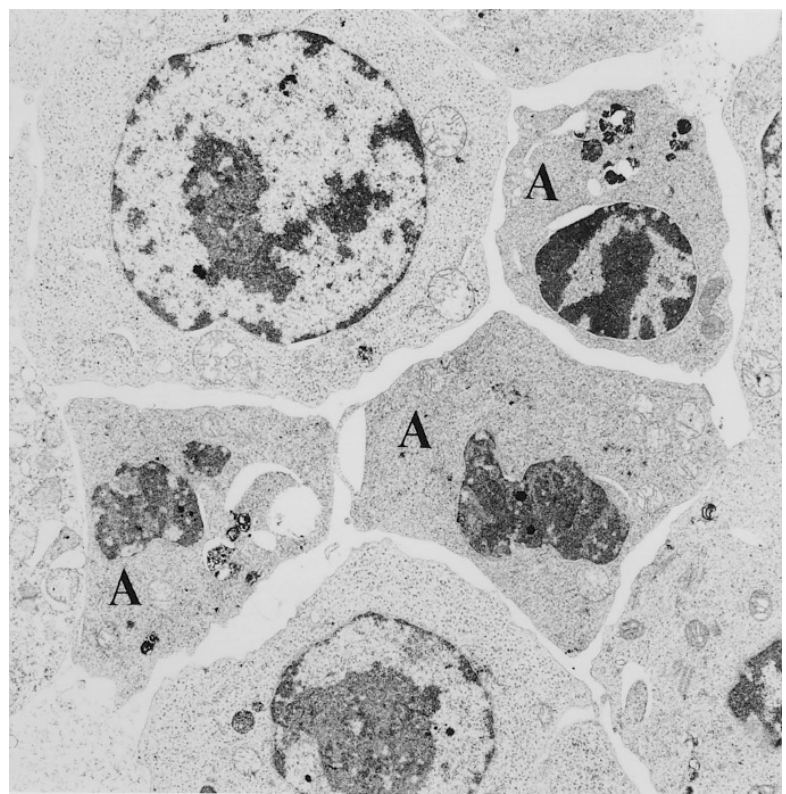

Figure 3 Ultrastructural alterations with serum withdrawal. Electron microscopy was used to determine the ultrastructure of $\mathrm{J} 2 \mathrm{E}$ cells in cultures deprived of serum. A-denotes cells that are undergoing apoptosis.
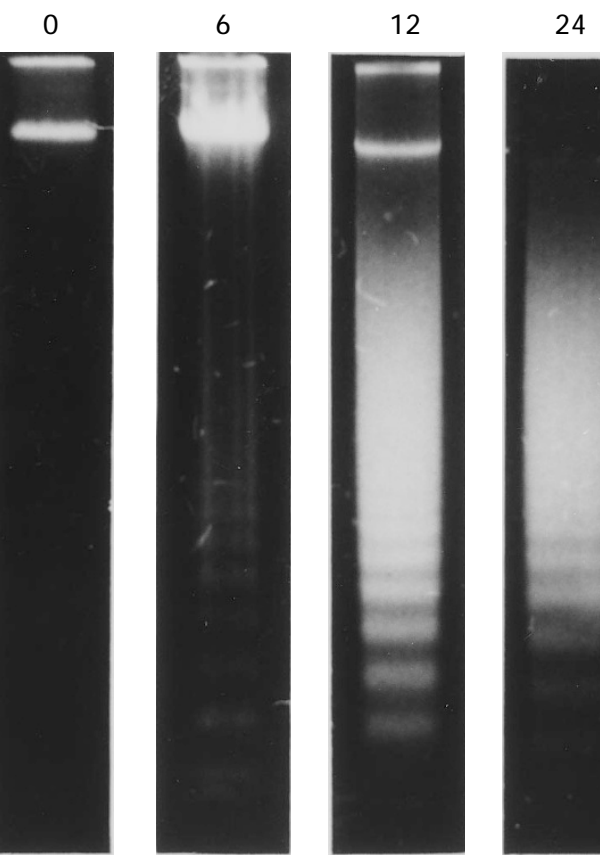

Figure 4 DNA degradation after serum withdrawal. J2E cultures were established without serum, then cells were collected at various times $(0-24 \mathrm{~h})$ for DNA extraction and separation on agarose gels.

\section{J2E cells are more susceptible to apoptosis than MEL cells}

The rate of cell death for J2E cells was compared with Friendvirus transformed murine erythroleukemic (MEL) cells because they are immortalized at similar stages of erythroid differentiation (Klinken et al, 1988; Dube et al, 1975). However, unlike the J2E line, MEL cells do not differentiate in response to epo and mature only with xenobiotic stimulation (Marks and Rifkind, 1978). Data presented in Table 1 show that the J2E cell died more rapidly following serum withdrawal than the MEL cells. Thus, the J2E cells appear to be inherently more sensitive to serum deprivation than a comparable erythroid cell line. In addition to dying when serum was removed, J2E cells also underwent apoptosis shortly after cultures became confluent (data not shown). In contrast, MEL cells grown in parallel were much more robust than J2E cells. One explanation for these observations is that $\mathrm{J} 2 \mathrm{E}$ cells are susceptible to cell death whenever replication is impeded.

To determine if J2E cells would die when cell division was impeded, cultures were established at low cell density with ample FCS, then inhibited from proliferating by addition of aphidicolin, a drug which inhibits the cell cycle at the

Table 1 Epo support viability of J2E cells but not MEL cells

\begin{tabular}{|c|c|c|c|c|}
\hline \multirow[b]{3}{*}{ Time (h) } & \multicolumn{4}{|c|}{ Viability ( $\%$ of control) } \\
\hline & & & & \\
\hline & - Epo & +Eро & - Epo & +Epo \\
\hline 0 & 100 & 100 & 100 & 100 \\
\hline 3 & $91 \pm 5$ & $100 \pm 1$ & $100 \pm 1$ & $100 \pm 3$ \\
\hline 6 & $72 \pm 6$ & $90 \pm 3^{a}$ & $100 \pm 2$ & $100 \pm 3$ \\
\hline 18 & $45 \pm 5$ & $71 \pm 5^{a}$ & $76 \pm 4$ & $74 \pm 5$ \\
\hline 24 & $21 \pm 4$ & $59 \pm 6^{b}$ & $70 \pm 4$ & $67 \pm 6$ \\
\hline
\end{tabular}

Cultures of J2E and MEL cells were washed thoroughly and grown in serum-free media. The effect of epo $(5 \mathrm{U} / \mathrm{ml})$ on the viability of cells was determined over $24 \mathrm{~h}$. Each value is the mean of three experiments $( \pm S D)$. ${ }^{\text {a Significant }}$ increase versus - epo $(P<0.01)$. ' Significant increase versus - epo $(P<0.001)$

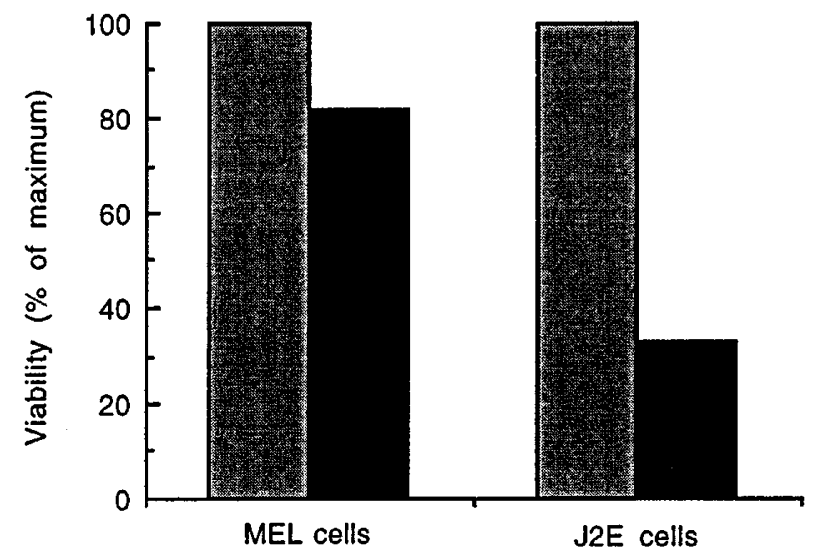

Figure $5 \mathrm{~J} 2 \mathrm{E}$ cells die when cultured with aphidicolin. Cultures of J2E and MEL cells were established in 10\% FCS with (black histogram) or without (stippled histogram) $2.5 \mathrm{mM}$ aphidicolin, a cell cycle inhibitor. The following day viabilities were determined. 
beginning of $S$ phase. In the presence of aphidicolin the viability of $\mathrm{J} 2 \mathrm{E}$ cells was reduced to $28 \%$ after $16 \mathrm{~h}$ (Figure 5). Analysis of the DNA content, together with cytocentrifuge preparations, clearly demonstrated an increase in DNA cleavage and the presence of apoptotic bodies (data not shown). Under identical conditions the viability of MEL cells decreased slightly to $82 \%$. These results indicate that $\mathrm{J} 2 \mathrm{E}$ cells are highly susceptible to apoptosis if they are unable to traverse the cell cycle.

\section{Epo prevents apoptosis of J2E cells}

It has been suggested that epo plays a crucial role in maintaining the viability of erythroid cells (Koury and Bondurant, 1988, 1990; Spivak et al, 1991). In addition, a number of other factors including stem cell factor (SCF),

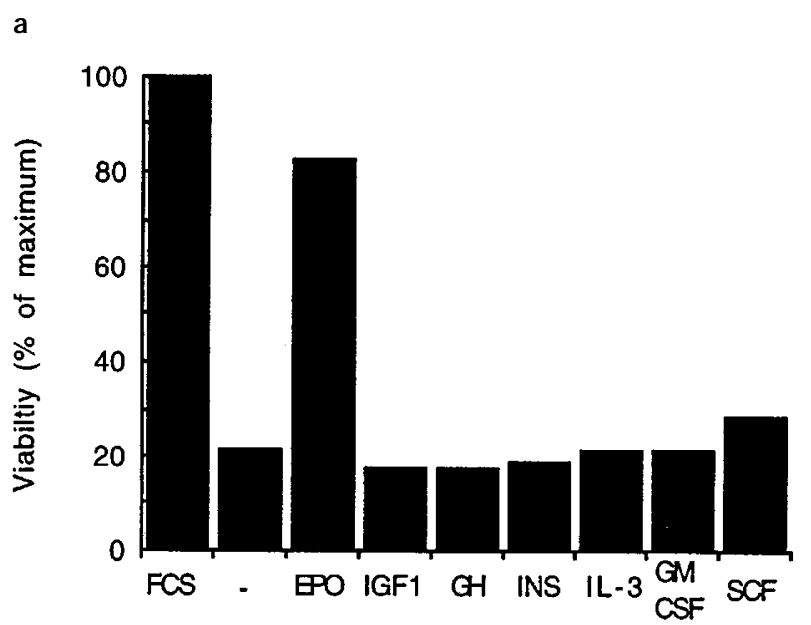

b

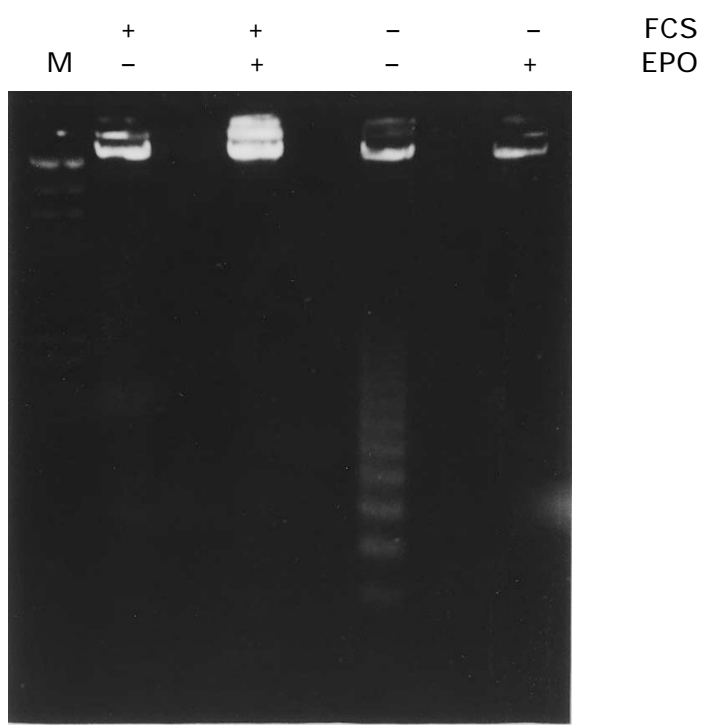

Figure 6 Epo protects J2E cells from apoptosis and DNA degradation. (a) J2E cells were washed thoroughly and replated in $10 \%$ FCS, no serum (-) or no serum plus $10 \mathrm{U} / \mathrm{ml}$ epo, IGF-1, growth hormone (GH), insulin (INS), IL-3, GM-CSF and SCF. Viabilities were determined $24 \mathrm{~h}$ later. (b) J2E cells were grown in the presence, or absence, of $10 \%$ FCS with, or without, $10 \mathrm{U} / \mathrm{ml}$ epo for $24 \mathrm{~h}$ before DNA was extracted and separated on agarose gels. interleukin 3 (IL-3), granulocyte-macrophage colony stimulating factor (GM-CSF), insulin, insulin-like growth factor 1 (IGF-1) and growth hormone are thought to be involved in promoting the survival of immature erythroid cells. These factors were added to cultures depleted of FCS to determine whether they could support the viability of J2E cells. Figure $6 \mathrm{a}$ and Table 1 show that epo could maintain the viability of J2E cells in the absence of FCS, whereas the other factors provided no protection from apoptosis. Furthermore, epo was able to restrict DNA degradation in the absence of FCS (Figure 6b). From these data we concluded that epo could act as a viability factor for these immature erythroid cells. In contrast, epo could not protect MEL cells from dying in the absence of serum (Table 1). However, epo is not the molecule present in FCS which maintains the viability of J2E cells (Figure 1b) as no detectable epo is present in the serum (data not shown).

To determine if the concentration of epo required to maintain the survival of J2E cells was the same as that required for induction of cell division and differentiation, a dose response curve to the hormone was generated. Figure 7 shows that proliferation and maturation peaked between 0.1 and $0.3 \mathrm{U} / \mathrm{ml}$ epo, as we have described previously (Busfield and Klinken, 1992; Tilbrook et al, 1996b). Significantly, maintenance of viability by epo occurred at almost exactly the same concentration. This indicated that cell survival was concentration dependent, and did not differ from the amount of epo necessary for proliferation and differentiation.

\section{JAK2 is required for the epo survival signal}

Immediately after binding its ligand the epo receptor dimerizes and the ancillary kinase JAK2 is activated, enabling signals to be transduced within the cell. Using antisense oligonucleotides we have shown elsewhere that JAK2 is essential, not

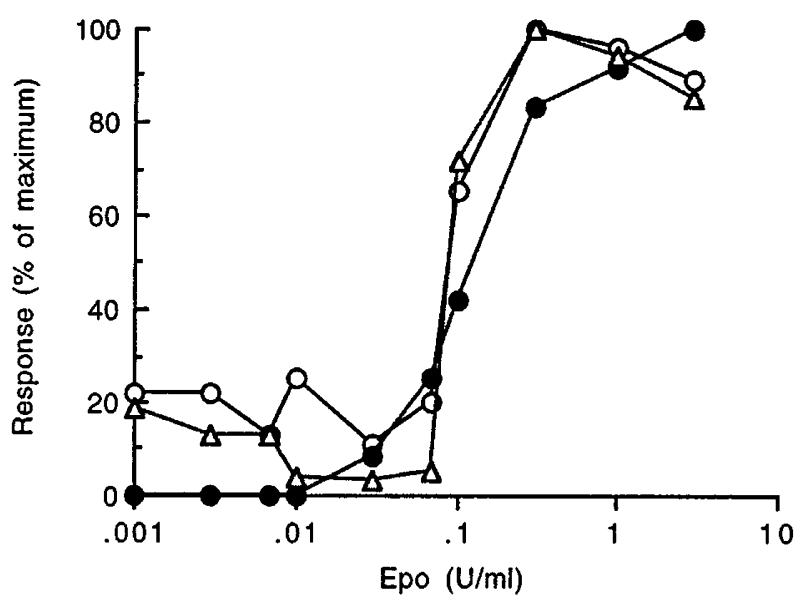

Figure 7 Viability dose response curve for J2E cells. J2E cells were grown in $10 \%$ FCS and exposed to a range of epo concentrations $(0.001-10 \mathrm{U} / \mathrm{ml})$ before $\left[{ }^{3} \mathrm{H}\right]$-thymidine incorporation (open triangles) was determined after $24 \mathrm{~h}$, and benzidine staining for haemoglobin production (closed circles) was measured at $48 \mathrm{~h}$. Simultaneously, cells were deprived of FCS and cultured with the same range of epo concentrations and viability (open circles) assessed after $24 \mathrm{~h}$. 
only for epo-induced proliferation, but also for differentiation (Tilbrook et al, 1996b). Here we tested the role of JAK2 in epo signalling for cell viability. Anti-sense oligonucleotides to JAK2 were added to J2E cultures and after 3 days JAK2 protein content was less than $10 \%$ of the original amount (Tilbrook et al, 1996b). Serum was then withdrawn from the cultures and viability assessed. Table 2 shows that by blocking JAK2, the ability of epo to promote cell survival was significantly suppressed. In contrast, a control oligonucleotide had no effect on viability. These data demonstrate that JAK2 plays an important role in epo-initiated signal transduction pathways which prevent cell death.

\section{Epo does not maintain viability via the MAP kinase pathway}

As epo activates the ras/MAP kinase signal transduction pathway in J2E cells (Tilbrook et al, 1996a), the effects of serum deprivation on raf and MAP kinases were investigated. Raf kinase was constitutively activated in J2E cells and the level of activity was maintained after FCS removal from culture (Figure 8). This result was not surprising as J2E cells were transformed by the $\mathrm{v}$-raf/v-myc containing $\mathrm{J} 2$ virus (Klinken et al, 1988). Immunoblotting revealed that p42 and

Table 2 Anti-sense JAK2 oligonucleotides suppress epo-supported viability

\begin{tabular}{lcc}
\hline Treatment & Viability (\%) & $\begin{array}{c}\text { Increase over control } \\
\text { (\%) }\end{array}$ \\
\hline Control & $8 \pm 4$ & 0 \\
Random oligo & $6 \pm 3$ & -25 \\
Anti-sense oligo & $8 \pm 3$ & 0 \\
Epo & $31 \pm 6$ & 287 \\
Epo \pm random oligo & $35 \pm 6$ & 337 \\
Epo \pm anti-sense oligo & $16 \pm 5^{\text {a }}$ & 100 \\
\hline
\end{tabular}

J2E cells were cultured with oligonucleotides for $72 \mathrm{~h}$ to reduce the level of JAK2 protein by $>90 \%$. They were then washed thoroughly and deprived of FCS. Epo and oligonucleotides were added as indicated and viabilities determined after $48 \mathrm{~h}$. Each value represents the mean of three experiments $(+S D)$. ${ }^{\text {a Significant }}$ decrease versus epo alone $(P<0.05)$ and epo \pm random oligo $(P<0.02)$



Figure 8 Activity of raf and MAP kinases after serum withdrawal. J2E cells were deprived of serum and the activity of raf (black histogram) determined over $6 \mathrm{~h}$. The phosphorylation status of p42 (hatched histogram) and p44 (stippled histogram) MAP kinases was followed for the same time period. p44 MAP kinases were highly phosphorylated during normal cell growth (Figure 9), due in part to the elevated raf activity. However, upon serum withdrawal the phosphorylation status of the MAP kinases declined appreciably, despite raf kinase activity being maintained (Figures 8 and 9 ). As reintroduction of FCS activated the MAP kinases (Figure 9), it appears that FCS, and not just an activated raf gene, is needed to maintain MAP kinase activity.

We have shown elsewhere that MAP kinase activity is linked to epo-induced differentiation (Tilbrook et al, 1996a), and others have demonstrated an association with the proliferative effects of epo (Miura et al, 1994; Todokoro et al, 1994; Bittorf et al, 1994; Gobert et al, 1995). As MAP kinase phosphorylation decreased markedly after serum withdrawal, we speculated that it may also be involved in viability signalling. To this end the anti-sense oligonucleotide strategy employed by Sale et al (1995) was used to determine the role of p42 and p44 MAP kinases in epoinduced survival. Table 3 shows that, unlike JAK2, inhibition of the MAP kinases made no difference to the maintenance of viability supported by epo. In these experiments, MAP kinase protein content was reduced by more than $70 \%$ and differentiation was suppressed accordingly. These data indicate that the MAP kinase pathway is not involved in regulating cell survival and are consistent with a role in differentiation.

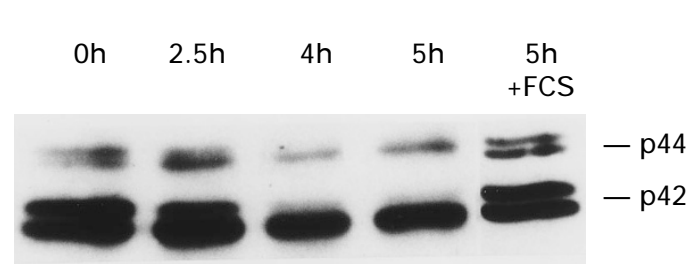

Figure 9 Dephosphorylation and reactivation of MAP kinases. Immunoblot showing the decrease in the phosphorylated (upper band) form of $p 42$ and p44 MAP kinases over several hours after serum deprivation. FCS was reintroduced after $5 \mathrm{~h}$ culture without serum.

Table 3 Anti-sense MAP kinase oligonucleotides inhibit differentiation but do not affect epo-supported viability

\begin{tabular}{lccc}
\hline Treatment & $\begin{array}{c}\text { Viability } \\
(\%)\end{array}$ & $\begin{array}{c}\text { Increase } \\
\text { over control } \\
\text { (\%) }\end{array}$ & $\begin{array}{c}\text { Benzidine } \\
\text { positive cells } \\
\text { (\%) }\end{array}$ \\
\hline Control & $6 \pm 2$ & 0 & $9 \pm 2$ \\
Random oligo & $6 \pm 2$ & 0 & $12 \pm 2$ \\
Anti-sense oligo & $7 \pm 3$ & 17 & $9 \pm 3$ \\
Epo & $18 \pm 4$ & 200 & $28 \pm 2$ \\
Epo+random oligo & $21 \pm 5$ & 250 & $22 \pm 3$ \\
Epo+anti-sense oligo & $21 \pm 4$ & 250 & $11 \pm 3^{\mathrm{a}}$ \\
\hline
\end{tabular}

J2E cells were cultured with oligonucleotides for $72 \mathrm{~h}$ and the levels of $\mathrm{p} 42$ and p44 MAP kinases fell by 84 and $72 \%$ respectively ( $v$-raf was used as the loading control). They were then washed thoroughly and deprived of FCS. Epo and oligonucleotides were added as indicated and viabilities determined after $48 \mathrm{~h}$. Parallel experiments to determine the effect on differentiation (as measured by benzidine staining) were conducted in the presence of FCS, $24 \mathrm{~h}$ after addition of epo. Each value is the mean of three experiments $( \pm S D)$. ${ }^{\text {a Significant }}$ decrease versus epo alone $(P<0.01)$ and epo+random oligo $(P<0.02)$ 


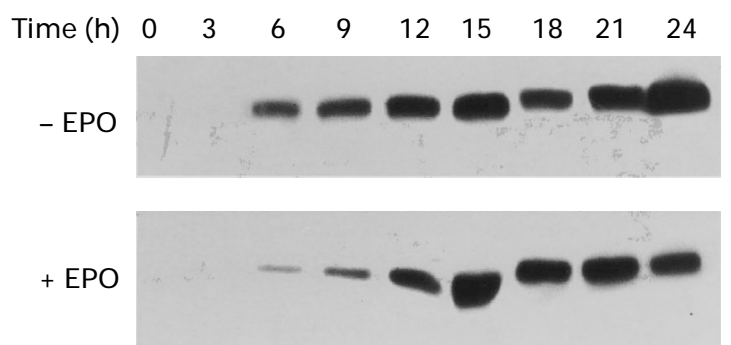

Figure $10 \mathrm{c}$-jun increases during apoptosis of J2E cells. (A) Cells were deprived of serum for $0-24 \mathrm{~h}$ and protein extracted for immunoblotting with anti-c-jun antibodies at various time points. (B) Cells were serum starved but cultured with $10 \mathrm{U} / \mathrm{ml}$ epo for $24 \mathrm{~h}$ before protein extracts were immunoblotted with anti-c-jun antibodies.

\section{c-jun increases during apoptosis}

Changes to a number of cell cycle proteins and transcription factors molecules have been associated with apoptosis. The following molecules were investigated to determine if they changed during programmed cell death of J2E cells and whether epo would reverse these effects: cdc 2 (p34), cdk 2 , cdk 4, cdk 5, proliferating cell nuclear antigen (PCNA), cyclin A, cyclin B1, cyclins D1-D3, cdc 25, fos, jun and myc. Most of the proteins did not alter after withdrawal of serum. However, cyclin B1 showed a transient increase which was not influenced by epo, and cyclin D3 underwent a brief elevation upon epo stimulation. In contrast, c-jun protein content rose appreciably within cells deprived of FCS (Figure 10). Similar increases in C-jun were observed when J2E cultures were overgrown and underwent apoptosis (data not shown). Increases in c-jun have been associated with the genesis of cell death in a number of cell systems (Colotta et al, 1992; Estus et al, 1994; Goldstone and Lavin, 1994). While epo could reduce death of J2E cells, it did not suppress the rise in c-jun (Figure 10). To determine if c-jun was involved in the apoptotic process, anti-sense oligonucleotides to the transcription factor were added to J2E cultures. However, inhibiting c-jun had no effect on apoptosis or the maintenance of viability promoted by epo (data not shown). We concluded that the rise in c-jun may not necessarily be responsible for cell death in J2E cells.

\section{Discussion}

J2E cells die rapidly when serum is withdrawn, bearing the hallmarks of apoptosis (Kerr et al, 1972; Wyllie et al, 1980; Raff, 1992). Microscopic analyses revealed nuclear condensation and fragmentation, reduced cell volume and condensed membrane-bound organelles. Nuclear disruption was associated with extensive DNA breakdown as evidenced by the increased number of cells with less than diploid DNA content, and the emergence of oligonucleosomal banding patterns. Commitment to cell death occurred $4 \mathrm{~h}$ after FCS withdrawal and significant loss in viability was seen thereafter. Similar effects have been observed in numerous haemopoietic systems after growth factor depletion e.g. when epo is withdrawn from Friend virus-infected erythroblasts and HCD57 cells (Koury and Bondurant 1988, 1990; Spivak et al,
1991), and when IL-3, GM-CSF or granulocyte colony stimulating-factor ( $\mathrm{G}-\mathrm{CSF})$ is removed from myelomonocytic FDCP cells (Williams et al, 1990).

Epo was able to protect J2E cells from apoptosis caused by serum depletion - viability of the cells was maintained and DNA breakdown reduced substantially. Several other factors were unable to prevent the inexorable progression to death. These results support the proposition that epo has the capacity to promote survival of erythroid precursor cells (Koury and Bondurant, 1988, 1990; Spivak et al, 1991). However, Friend virus-infected erythroblasts are heterogenous in their susceptibility to apoptosis, and DNA breakdown is inhibited over a wide range of epo concentrations (Kelley et al, 1993), whereas the clonal $\mathrm{J} 2 \mathrm{E}$ line responds to epo over the narrow dose response range that also initiates cellular maturation (Busfield and Klinken, 1992). Interestingly, apoptosis of erythroblasts deprived of epo can occur at any stage of the cell cycle (Kelley et al, 1994).

JAK2 appears to be intimately involved in the survival signal transmitted by epo. Suppression of JAK2 with antisense olignucleotides not only prevented proliferation and differentiation of J2E cells (Tilbrook et al, 1996b), but also restricted the maintenance of viability by epo (Table 2 ). This result is compatible with the data of Zhuang et al (1995), who noted that JAK2 was involved in epo signalling for maintaining viability in myeloid FDCP-1 cells transfected with epo receptor and JAK2 constructs. Our studies extend their observations to show the involvement of JAK2 with epo-induced viability in an erythroid cell line. Both studies suggest that phosphorylation of the receptor via JAK2 may play an important role in viability signalling, or alternatively, JAK2 has some direct role in supporting survival. It is noteworthy that JAK2 can be activated in a mutant clone of J2E cells (J2E-NR) which does not proliferate or differentiate in response to epo, but does remain alive when epo is present (Tilbrook et al, 1996a). The role of STATs in JAK2 signalling in erythroid cells is unclear at present. There have been numerous reports on epo activating STATs (Damen et al, 1995; Penta and Sawyer, 1995; Quelle et al, 1996; Ohashi et al, 1995; Gouilleux et al, 1995; Tilbrook et al, 1996b) but whether they participate in proliferation, differentiation or viability remains to be determined.

The commitment to programmed cell death in J2E cells also occurred whenever the cells' capacity to divide was restricted. Attainment of confluence, exposure to aphidicolin and withdrawal of FCS were all associated with reduced cell division and subsequent apoptosis. This susceptibility of $\mathrm{J} 2 \mathrm{E}$ cells to apoptosis may be linked with dysregulation of the myc gene, as the cells contain an aberrant $\mathrm{v}$-myc in the $\mathrm{J} 2$ virus (Klinken et al, 1988). Constitutive expression of c-myc in fibroblasts and IL-3, or epo-, dependent myeloid cells has been shown to promote cell death when proliferation is blocked (Evan et al, 1992; Shi et al, 1992; Askew et al, 1991). It has been postulated that c-myc induces mitosis when activated in conjunction with another growth signal; in the absence of the secondary signal, mycmediated cell death occurs (Harrington et al, 1994). Clearly there are factors present in FCS which provide additional 
signals for proliferation of J2E cells - if these are removed, or cell division is inhibited by other means, the J2E cells die. However, in contrast with the data presented here, Askew et al (1993) observed that epo was unable to prevent apoptosis in $32 \mathrm{D}$ myeloid cells inappropriately expressing c-myc.

The J2E erythroid cells were far more susceptible to apoptosis than MEL cells which are immortalized at a similar stage of erythroid development (Marks and Rifkind, 1978). The difference in viability between these cell lines is consistent with aberrant myc expression in J2E, but not MEL cells. Significantly, J2E cells could be protected from cell death by epo, whereas MEL cells were not. This inability could reflect binding of the viral gp55 protein to the epo receptor in MEL cells (Li et al, 1990), or result from the severe truncation to the cytoplasmic domain of the receptor that we have observed recently (Bittorf et al, 1996). Therefore, in addition to being unable to differentiate or proliferate in response to epo, MEL cells are incapable of transducing any epo-initiated viability signals.

J2E cells also constitutively express the v-raf oncogene and it has been suggested that raf may suppress apoptosis (Cleveland et al, 1994), possibly via a link with bcl2 (Wang et al, 1994). In this case raf appears to provide little protection from rapid cell death - perhaps the effect of myc on apoptosis is dominant over raf? As raf is upstream of MAP kinase in the phosphorylation cascade, it was not surprising to observe that the MAP kinases were highly phosphorylated in J2E cells. However, with serum deprivation raf kinase activity remained unaltered, while MAP kinase activation fell precipitously. There appear to be two explanations for this phenomenon: (i) $v$-raf is not entirely responsible for the phosphorylation status of MAP kinases in J2E cells and serum factors also contribute to its activation, (ii) a phosphatase (perhaps a MAP kinase specific phosphatase) is stimulated with FCS depletion. Although MAP kinases could be partially re-activated by FCS, serum factors are also mitogenic and it is conceivable that the phosphorylation of MAP kinases is related to intracellular signalling for proliferation, rather than for maintaining viability. Two pieces of evidence support the concept that the MAP kinase pathway is associated with proliferation and differentiation, but not survival. First, J2ENR cells remain alive in the presence of the epo and MAP kinases are not activated (Tilbrook et al, 1996a). Second, down-regulation of MAP kinases with anti-sense oligonucleotides had no effect on epo-stimulated viability of J2E cells (Table 3 ). The data agree with the observation that v$a b /$ suppression of apoptosis is independent of MAP kinase activation (Owen-Lynch et al, 1995).

\section{Materials and Methods}

\section{Cell culture}

J2E cells (Klinken et al, 1988) and MEL cell line, F4N (Dube et al, 1975) were cultured in Dulbecco's modified Eagle's medium (DMEM) supplemented with $10 \%$ FCS. Recombinant growth factors used in these studies were: $10 \mathrm{U} / \mathrm{ml}$ human epo (Eprex; Janssen-Cilag Sydney, Australia), $100 \mathrm{U} / \mathrm{ml}$ SCF (a gift from Dr P Steinlein, Institute for Molecular Pathology, Vienna, Austria), $100 \mathrm{U} / \mathrm{ml} \mathrm{IL-3}$ and GMCSF (gifts from Dr Nicos Nicola, Walter and Eliza Hall Institute, Melbourne, Australia), $100 \mathrm{U} / \mathrm{ml}$ insulin (Commonwealth Serum Laboratories, Melbourne, Australia), $100 \mathrm{U} / \mathrm{ml} \mathrm{IGF-1} \mathrm{and} 100 \mathrm{U} / \mathrm{ml}$ growth hormone (gifts from $\mathrm{Dr} G$ Werther, Royal Children's Hospital, Melbourne, Australia). Aphidicolin (Sigma, St Louis, Mo, USA) was used at a final concentration of $2.5 \mathrm{mM}$.

\section{Cytocentrifuge preparations and electron microscopy}

Cells were cytocentrifuged at $300 \mathrm{rpm}$ for $5 \mathrm{~min}$ onto glass slides using a cytospin 2 (Shandon, Cheshire, UK) and fixed with methanol. May-Grunwald-Geimsa stain (BDH, Poole, England), bisbenzimide H33258 (Calbiochem-Novabiochem, San Diego, CA, USA) or acridine orange (Sigma, St Louis, MO, USA) were placed on the slides for $5 \mathrm{~min}$, washed in Sorenson's buffer $\left(66 \mathrm{mM} \mathrm{Na} \mathrm{HPO}_{4}, 66 \mathrm{mM}\right.$ $\mathrm{KH}_{2} \mathrm{PO}_{4}$ ) and then viewed with either a Zeiss light microscope or a Leitz Ortholux 2 fluorescence microscope and photographed with a Leitz Orthomat 2 camera. Cell viability was determined by exclusion of $0.4 \%$ eosin as viewed on a haemocytometer (Klinken et al, 1988; Busfield and Klinken, 1992), while differentiation was quantitated by benzidine staining of haemoglobin producing cells (Cooper et al, 1974). Apotag was purchased from ONCOR (Gaithersberg, MD, USA). For ultrastructural analyses cells were fixed in $2.5 \%$ paraformaldehyde $/ 2.5 \%$ glutaraldehyde, sectioned, stained with uranylacerate and viewed under a Philips 410 electron microscope as described previously (Busfield et al, 1993c).

\section{Cell cycle analysis and $\left[{ }^{3} \mathrm{H}\right]$-thymidine incorporation}

Cells were prepared for cycle analysis by adding $0.25 \%$ Triton X-100 and $250 \mathrm{mM}$ propidium iodide to $10^{6}$ cells. The stained nuclei were then analyzed on a FACScan II unit (Becton Dickinson, Mountain View, CA, USA) and the proportion of cells in each phase of the cell cycle calculated (Busfield and Klinken, 1992). To measure DNA synthesis $0.5 \mu \mathrm{Ci}\left[{ }^{3} \mathrm{H}\right]$-thymidine $\left(25 \mathrm{mCi} / \mathrm{mmol}\right.$ [methyl- $\left.{ }^{3} \mathrm{H}\right]$-thymidine; Amersham, Bucks, UK) was added to $5 \times 10^{4}$ cells for $6 \mathrm{~h}$. DNA was then collected onto glass fibre filters (Whatman, Kent, UK) using a microharvester (Skatron, Lier, Norway) and incorporation of labelled nucleotide measured by scintillation counting in a Beckman LS 6800 counter (Busfield and Klinken, 1992).

\section{Data analysis}

DNA integrity was assessed by a modification of the method of Strange et al (1992) as used by us previously (Tilbrook et al, 1996a). Cells were pelleted, lysed with $6 \mathrm{M}$ guanidine hydrochloride (BRL Life Technologies, MD, USA) and nucleic acids precipitated with ethanol. The pellet was then resuspended in $10 \mathrm{mM}$ Tris, $10 \mathrm{mM}$ EDTA, $10 \mathrm{mM}$ $\mathrm{NaCl}, 0.5 \%$ SDS. $0.2 \mu \mathrm{g} / \mathrm{ml}$ proteinase $\mathrm{K}$ and incubated at $50^{\circ} \mathrm{C}$ overnight. After phenol/chloroform extraction and ethanol precipitation the pellet was resuspended in $10 \mathrm{mM}$ Tris, $1 \mathrm{mM}$ EDTA $20 \mathrm{mg} / \mathrm{ml}$ RNase A (Sigma) and incubated at $37^{\circ} \mathrm{C}$ for $1 \mathrm{~h}$. The DNA content was determined by staining with bisbenzimide $\mathrm{H} 33258$ (CalbiochemNovabiochem), according to the method of Labraco and Paigen (1980), before $7.5 \mu \mathrm{g}$ of each sample was separated through a $1 \%$ agarose gel. 


\section{Protein analysis}

J2E cells were washed three times in DMEM and resuspended at 2$5 \times 10^{5}$ cells/ml DMEM. For MAP kinases analysis, cells were incubated for up to $5 \mathrm{~h}$ before re-addition of $10 \%$ FCS for $30 \mathrm{~min}$. For transcription factor and cell cycle protein analyses, cells were incubated for up to $24 \mathrm{~h}$ in the presence or absence of epo $(5 \mathrm{U} / \mathrm{ml})$. Cells were lysed and proteins analysed by immunoblotting with antiMAP kinase (Erk 1), jun, fos, myc, cdc 2(p34), cdk2, cdk4, cdk5, PCNA, cyclins $A_{1}, B_{1}, D_{1}, D_{2}, D_{3}$, and cdc 25 antibodies (Santa Cruz Biotechnology, CA, USA) as described previously (Busfield et al, 1995a,b; Callus et al, 1995; Tilbrook et al, 1996a,b).

\section{Raf activity}

J2E cells were washed three times in DMEM, resuspended at $2 \times 10^{6} /$ $\mathrm{ml}$ and incubated for up to $6 \mathrm{~h}$ in DMEM without serum. Cells were lysed and $1 \mathrm{mg}$ protein immuno-precipitated with anti-raf antibody (Santa Cruz Biotechnology) as described previously (Busfield et al, 1995a; Tilbrook et al, 1996a,b). The immunoprecipitates were washed in kinase buffer ( $25 \mathrm{mM}$ HEPES pH 7.4, $25 \mathrm{mM} \beta$-glycerol phosphate, $1 \mathrm{mM}$ DTT, $10 \mathrm{mM} \mathrm{MgCl}$ ), resuspended in $100 \mu$ l kinase buffer with $20 \mu \mathrm{Ci}\left[{ }^{32} \mathrm{P}\right] \gamma$ ATP (Amersham), $0.1 \mathrm{mM}$ ATP and either $20 \mu \mathrm{g}$ Syntide (Santa Cruz Biotechnology) or $200 \mu$ g myelin basic protein (Sigma) for $20 \mathrm{~min}$ at $30^{\circ} \mathrm{C}$. The reaction was terminated by addition of $1 \times$ Laemelli buffer, the samples were then separated on an $8-25 \%$ gradient gel, which was later dried and exposed to X-ray film. Incorporation of $\left[{ }^{32} \mathrm{P}\right] \gamma$ ATP into the substrate was quantitated densitometrically.

\section{Anti-sense oligonucleotide protocols}

Phosphorothioate modified oligonucleotides were purchased from Macromolecular Resources (CO, USA) and Biognostik (Göttingen, Germany). Anti-sense oligo-nucleotides were generated to JAK2 (5'GCT TGT GAG AAA GC-3'), p42 and p44 MAP kinases (5'-GCC GCC GCC GCC GCC AT-3') and c-jun (5'-CGT TTC CAT CTT TGC AGT-3') as described previously (Tilbrook et al, 1996b; Sale et al, 1995; Soprano et al, 1992). The random/scrambled oligonucleotides were 5'-GTC CCT ATA CGA AC-3' (Tilbrook et al, 1996b), 5'-CGC GCG CTC GCG CAC CC-3' (Sale et al, 1995) and 5'-CGT GTC AAT AAT GGC AGT-3' (Soprano et al, 1992). J2E cells were established at $5 \times 10^{4}$ cells $/ \mathrm{ml}$ and incubated with $2-10 \mu \mathrm{M}$ oligonucleotide for three days; cultures were diluted to $5 \times 10^{4}$ cells $/ \mathrm{ml}$ daily and the oligonucleotide replenished. Cells were then washed three times in DMEM, replated at $3-5 \times 10^{5}$ cells $/ \mathrm{ml}$ with $2-10 \mu \mathrm{M}$ oligonucleotide and epo $(5 \mathrm{U} / \mathrm{ml})$. Cultures were maintained for a further $24-48 \mathrm{~h}$ and the oligonucleotide was replenished after $24 \mathrm{~h}$. Protein levels were analysed by Western blots and quantitated by densitometry. Statistical significance was demonstrated by students t-test where a $P$ value of $<0.05$ was considered significant.

\section{Acknowledgements}

This work was supported by grants from the NH\&MRC (\#96-0581), the Raine Medical Research Foundation, the Australian Kidney Foundation and the Cancer Foundation of Western Australia. We are grateful to Drs J Adams, P Steinlein, N Nicola and G Werther for kind donations of growth factors, and to $L$ Conte for preparing the manuscript.

\section{References}

Askew DS, Ashmun RA, Simmons BC and Cleveland JL (1991) Constitutive c-myc expression in an IL-3-dependent myeloid cell line suppresses cell cycle arrest and accelerates apoptosis. Oncogene. 6: 1915-1922

Askew DS, Ihle JN and Cleveland V (1993) Activation of apoptosis associated with enforced myc expression in myeloid progenitor cells is dominant to the suppression of apoptosis by interleukin-3 or erythropoietin. Blood. 82: 20792087

Bittorf T, Jaster R and Brock J (1994) Rapid activation of the MAP kinase pathway in haemopoietic cells by erythropoietin. Cell Signalling. 6: 305-311

Bittorf T, Busfield SJ, Klinken SP and Tilbrook PA (1996) Truncated erythropoietin receptor in a murine erythroleukemia cell line. Int. J. Biochem. 28: 175-181

Boise LH, Minn AJ, June CH, Lindsten T and Thompson CB (1995) Growth factors can enhance lymphocyte survival without committing the cell to undergo cell division. Proc. Natl. Acad. Sci. USA. 92: 5491-5495

Busfield SJ and Klinken SP (1992) Erythropoietin-induced stimulation of differentiation and proliferation in J2E cells is not mimicked by chemical induction. Blood. 80: 412-419

Busfield SJ and Klinken SP (1993a) Retrovirally-produced erythropoietin effectively induces differentiation and proliferation of J2E erythroid cells. Growth Factors. 9: $87-97$

Busfield SJ, Farr TJ, Singh T, Sainsbury AJ and Klinken SP (1993b) Clonal analysis of erythropoietin stimulated J2E cells reveals asynchrony during terminal differentiation. Growth Factors. 9: 307-315

Busfield SJ, Meyer GT and Klinken SP (1993c) Erythropoietin induced ultrastructural alterations to $\mathrm{J} 2 \mathrm{E}$ cells and loss of proliferative capacity with terminal differentiation. Growth Factors. 9: 317-328

Busfield SJ, Chappell DS, Jennings G, Trengove NJ, Riches KJ, Callus BA, Tilbrook PA and Klinken SP (1995a) Erythropoietin exerts transcriptional and translational control over globin synthesis in J2E Cells. Cell Growth Differentiation. 6: 429-437

Busfield SJ, Spadaccini A, Riches KJ, TilbrookPA and Klinken SP (1995b) The major erythroid DNA-binding protein GATA-1 is stimulated by erythropoietin but not by chemical inducers of erythroid differentiation. Eur. J. Biochem. 230: 475-480

Callus B, Tilbrook PA, Busfield SJ, Cull VS, Bittorf T and Klinken SP (1995) Amiloride suppresses erythropoietin-induced proliferation and MAP kinase, but potentiates differentiation of J2E cells. Exp. Cell. Res. 219: 39-46

Cleveland JL, Troppmair J, Packham G, Askew DS, Lloyd P, Gonzalez-Garica M, Nunez G, Ihle JN and Rapp UR (1994) v-rafsuppresses apoptosis and promotes growth of interleukin-e-dependent myeloid cells. Oncogene. 9: 2217-2226

Colotta F, Polentarutti N, Sironi M and Mantovani A (1992) Expression and involvement of $\mathrm{c}$-fos and $\mathrm{c}$-jun protooncogenes in programmed cell death induced by growth factor deprivation in lymphoid cell lines. J. Biol. Chem. 267: $18278-18283$

Cooper MC, Levy J, Cantor LN, Marks PA and Rifkind RA (1974) The effect of erythropoietin on colonial growth of erythroid precursor cells in vitro. Proc. Natl. Acad. Sci. USA. 71: 1677-1680

Damen JE, Wakao H, Miyajima A, Krosl J, Humphries RK, Cutler RL and Krystal G (1995) Tyrosine 343 in the erythropoietin receptor positively regulates erythropoietin-induced cell proliferation and Stat5 activation. EMBO J. 14: 5557-5568

Dube SK, Pragnell IB, Kluge N, Gaedicke G, Steinheider G and Ostertag W (1975) Induction of endogenous and of spleen focus-forming viruses during dimethylsulfoxide-induced differentiation of mouse erythroleukemia cells transformed by spleen focus-forming virus. Proc. Natl. Sci. USA. 72: 1863-1867

Estus S, Zaks WJ, Freeman RS, Gruda M, Bravo R, Johnson EM Jr (1994) Altered gene expression in neurons during programmed cell death: identification of c-jun as necessary for neuronal apoptosis. J. Cell. Biol. 127: 1717-1727

Evan GI, Wyllie AH, Gilbert CS, Littlewood TD, Land H, Brooks M, Waters CM, Penn LZand Hancock DC (1992) Induction of apoptosis in fibroblasts by c-myc protein. Cell. 69: $119-128$

Gobert S, Duprez V, Lacombe C, Gisselbrecht S and Mayeux P (1995) The signal transduction pathway of erythropoietin involves three forms of mitogen-activated protein (MAP) kinase in UT7 erythroleukemia cells. Eur. J. Biochem. 234: 75-83

Goldstone SD and Lavin MF (1994) Prolonged expression of c-jun and associated activity of the transcription factor AP-1, during apoptosis in a human leukaemic cell line. Oncogene. 9: 2305-2311 
Gouilleux F, Pallard C, Dusanter-FourtI, Wakao H, Haldosen L-A, Norstedt G, Levy D and Groner B (1995) Prolactin, growth hormone, erythropoietin and granulocytemacrophage colony stimulating factor induce MGF-Stat5 DNA binding activity. EMBO J. 14: 2005-2013

Harrington EA, Bennett MR, Fanidi A and Evan GI (1994) c-Myc-induced apoptosis in fibroblasts is inhibited by specific cytokines. EMBO J. 13: 3286-3295

Ihle J (1995) Cytokine receptor signalling. Nature. 377: 591-594

Inhorn RC, Carlesso N, Durstin M, Frank DA and Griffin JD (1995) Identification of a viability domain in the granulocyte/macrophage colony-stimulating factor receptor $\beta$-chain involving tyrosine-750. Proc. Natl. Acad. Sci. USA. 92: $8665-8669$

Jelkmann W (1992) Erythropoietin: structure, control of production, and function Physiol. Rev. 72: 449-489

Kelley LL, Koury MJ, Bondurant MC, Koury ST, Sawyer ST and Wickrema A (1993) Survival or death of individual proerythroblasts results from differing erythropoietin sensitivities: a mechanism for controlled rates of erythrocyte production. Blood. 82: 2340-2352

Kelley LL, Green WF, Hicks GG, Bondurant MC, Koury MJ and Ruley HE (1994) Apoptosis in erythroid progenitors deprived of erythropoietin occurs during the $\mathrm{G}_{1}$ and $\mathrm{S}$ phases of the cell cycle without growth arrest or stabilisation of wild-type p53. Mol. Cell. Biol. 14: 4183-4192

Kerr JF, Wyllie AH and Currie AR (1972) Apoptosis: a basic biological phenomenon with wide-ranging implications in tissue kinetics. Br. J. Cancer. 26: 239-257

Kinoshita T, Yokota T, Arai K-i and Miyajima A(1995) Suppression of apoptotic death in hematopoietic cells by signalling through the IL-3/GM - CSF receptors. EMBO J. 14: $266-275$

Klinken SP, Nicola NA and Johnson G (1988) In-vitro-derived leukemic erythroid cell lines induced by a raf- and myc-containing retrovirus differentiate in response to erythropoietin. Proc. Natl. Acad. Sci. USA. 85: 8506-8510

Koury MJ and Bondurant MC (1988) Maintenance by erythropoietin of viability and maturation of murine erythroid precursor cells. J. Cell. Physiol. 137: 65-74

Koury MJ and Bondurant MC (1990) Erythropoietin retards DNA breakdown and prevents programmed death in erythroid progenitor cells. Science. 248: $378-$ 381

Koury MJ and Bondurant MC (1992) The molecular mechanism of erythropoietin action. Eur. J. Biochem. 210: 649-663

Krantz SB (1991) Erythropoietin. Blood. 77: 419-434

Labraco C and Paigen K (1980) A simple, rapid and sensitive DNA assay procedure. Anal. Biochem. 102: $344-352$

Li J-P, D'Andrea A, Lodish HF and Baltimore D (1990) Activation of cell growth by binding of Friend spleen focus forming virus gp55 glycoprotein to the erythropoietin receptor. Nature. 343: $762-764$

Liboi E, Carroll M, D'Andrea AD and Mathey-Prevot B (1993) Erythropoietin receptor signals both proliferation and erythroid-specific differentiation. Proc. Natl. Acad. Sci. USA. 90: 11351-11355

Marks PA and Rifkind RA (1978) Erythroleukemic differentiation. Ann. Rev. Biochem. 47: $419-448$

Miura Y, Miura O, Ihle JN and Aoki N (1994) Activation of the mitogen-activated protein kinase pathway by the erythropoietin receptor. J. Biol. Chem. 269: 29962-29969

Noguchi T, Fukumoto H, Mishina Y and Obinata M (1988) Differentiation of erythroid progenitor (CFU-E) cells from mouse fetal liver cells and murine erythroleukemia (TSA8) cells without proliferation. Mol. Cell. Biol. 8: 2604-2609

Ohashi T, Masuda M and Ruscetti SK (1995) Induction of sequence-specific DNAbinding factors by erythropoietin and the spleen focus-forming virus. Blood. 85 $1454-1462$
Okuda K, Ernst TJ and Griffin JD (1994) Inhibition of p21 ${ }^{\text {ras }}$ activation blocks proliferation but not differentiation of interleukin-3-dependent myeloid cells. J. Biol. Chem. 269: 24602-24607

Owen-Lynch PJ, Wong AK, Whetton AD (1995) v-abl-mediated apoptotic suppression is associated with SHC phosphorylation without concomitan mitogen-activated protein kinase activation. J. Biol. Chem. 270: 5956-5962

Penta K and Sawyer ST (1995) Erythropoietin induces the tyrosine phosphorylation, nucleartranslocation, and DNA binding of STAT1 and STAT5 in erythroid cells. J. Biol. Chem. 270: $31282-31287$

Quelle FW, Wang D, Nosaka T, ThierfelderWE, Stravopodis D, Weinstein Y and Ihle J (1996) Erythropoietin induces activation of Stat5 through association with specific tyrosines on the receptor that are not required for a mitogenic response. Mol. Cell. Biol. 16: 1622-1631

Raff MC (1992) Social controls on cell survival and cell death. Nature. 356: 397-400.

Sale EM, Atkinson PGP and Sale GJ (1995) Requirement of MAP kinases for differentiation of fibroblasts to adipocytes, for insulin activation of p90 S6 kinase and for insulin or serum stimulation of DNA synthesis. EMBO J. 14: 674-684

Shi Y, Glynn JM, Guilbert LJ, Cotter TG, Bissonnette RP and Green DR (1992) Role for c-myc in activation-induced apoptotic cell death in $\mathrm{T}$ cell hybridomas. Science. 257: 212-214

Soprano KJ, Cosenza SC, Yumet G and Soprano DR (1992) Use of antisense oligomers to study the role of c-jun in $\mathrm{G}_{1}$ progression. Ann. N.Y. Acad. Sci. 660: $231-239$

SpivakJL, Pham T, Isaacs Mand Hankins WD (1991) Erythropoietin is both a mitogen and a survival factor. Blood. 77: 1228-1233

Strange R, Li F, Saurer S, Burukhardt A and Friis RR (1992) Apoptotic cell death and tissue remodelling during mouse mammary gland involution. Development. 115: $49-58$

Sytkowski AJ, Salvado AJ, Smith GM and McIntyre CJ(1980) Erythroid differentiation of clonal rauscher erythroleukemia cells in response to erythropoietin or dimethyl sulfoxide. Science. 210: 74-76

Tilbrook PA, Bittorf T, Busfield SJ, Chappell D and Klinken SP (1996a) Disrupted signaling in a mutant J2E cell line that shows enhanced viability but does not proliferate or differentiate, with erythropoietin. J. Biol. Chem. 271: 3453-3459

Tilbrook PA, Bittorf T, Callus B, Busfield SJ, Ingley E and Klinken SP (1996b) Regulation of the erythropoietin receptor and involvement of JAK2 in differentiation of J2E erythroid cells. Cell Growth Diff. 7: 511-520

Todokoro K, Sugiyama M, Nishida E and Nakaya K (1994) Activation of mitogenactivated protein kinase cascade through erythropoietin receptor. Biochem. Biophys. Res. Comm. 203: 1912-1919

Wang H-G, Miyashita T, Takayama S, Sato T, Torigoe T, Krajewski S, Tanaka S, Hovey L III, Troppmair J, Rapp UR and Reed JC (1994) Apoptosis regulation by interaction of Bcl-2 protein and Raf-1 kinase. Oncogene. 9: 2751-2756

Williams GT, Smith CA, Spooncer E, Dexter TM and Taylor DR (1990) Haemopoietic colony stimulating factors promote cell survival by suppressing apoptosis. Nature. 343: 76-79

Wojchowski DM and He T-C (1993) Signal transduction in the erythropoietin receptor system. Stem Cells. 11: $381-392$

Wyllie AH, Kerr JFR, Currie AR (1980) Cell death: the significance of apoptosis. Int. Rev. Cytology. 68: 251-305

Zhuang H, Niu Z, He T-C, Patel SV and Wojchowski DM (1995) Erythropoietindependent inhibition of apoptosis is supported by carboxyl-truncated receptor forms and blocked by dominant-negative forms of JAK2. J. Biol. Chem. 270: $14500-14504$ 